\title{
Canopy Variation Among Three Sweet Corn Hybrids and Implications for Light Competition
}

\author{
Martin M. Williams II ${ }^{\mathbf{1}}$ \\ U.S. Department of Agriculture-Agricultural Research Service, Invasive \\ Weed Management Research, University of Illinois, 1102 S. Goodwin Avenue, \\ Urbana, IL 61801
}

Rick A. Boydston

U.S. Department of Agriculture-Agricultural Research Service, Vegetable and Forage Crops Research, 24106 N. Bunn Road, Prosser, WA 99350

Adam S. Davis

U.S. Department of Agriculture-Agricultural Research Service, Invasive Weed Management Research, University of Illinois, 1102 S. Goodwin Avenue, Urbana, IL 61801

Additional index words. canopy architecture, competitiveness, light interception, maize, weed interference, weed management, Zea mays

\begin{abstract}
Research in dent corn has found significant variation in crop/weed competition for light among hybrids. However, little has been published on the extent of variation in sweet corn competitive ability. Field studies were conducted under weed-free conditions to quantify canopy development and light environment among three sweet corn hybrids and to determine associations among canopy characteristics to crop yield. An early-season hybrid (Spirit) and two midseason hybrids (WHT2801 and GH2547) were grown at experimental sites located near Urbana, Ill., and Prosser, Wash., in 2004 and 2005. Maximum leaf area index (LAI) and intercepted photosynthetically active radiation (PAR) was typically highest for GH2547 and lowest for Spirit. Most differences in vertical LAI among hybrids was observed above 60 and $150 \mathrm{~cm}$ in Illinois and Washington, respectively, with WHT2801 and GH2547 having leaf area distributed higher in the canopy than Spirit. Both number and mass of marketable ears were positively correlated with maximum relative growth rate (correlation coefficients $0.60-0.81$ ), leaf area duration $(0.68-0.79)$, total LAI (0.56-0.74) at R1, and intercepted PAR (0.74-0.83) at R1. Differences in canopy properties and interception of solar radiation among Spirit, WHT2801, and GH2547 lead us to hypothesize that variation in weed-suppressive ability exists among hybrids. Future testing of this hypothesis will provide knowledge of interactions specific to sweet corn useful for developing improved weed management systems.
\end{abstract}

Crop photosynthesis is determined by capture and utilization of solar energy, and because light cannot be stored, competition for this resource in mixed canopies is an instantaneous process. Canopy properties that determine light interception by plant species are leaf area index (LAI), plant height, vertical leaf area distribution, and leaf angle (Sinoquet and Caldwell, 1995). Im-

Received for publication 3 May 2006. Accepted for publication 2 June 2006. We appreciate the technical assistance of John Frihauf, Ryan Hasty, Brian Philiben, Dallas Spellman, and Yim So. We also recognize Jerald "Snook" Pataky for his encouragement and advice in pursuing this research. Rogers Brand Vegetable Seed kindly provided sweet corn seed. Mention of a trademark, proprietary product, or vendor does not constitute a guarantee or warranty of the product by the U.S. Department of Agriculture and does not imply its approval to the exclusion of other products or vendors that also may be suitable.

${ }^{1}$ To whom reprint requests should be addressed; e-mailmmwillms@uiuc.edu. proving the crop's ability to avoid stress, preempt resources from weeds, or endure competitive stress (collectively called "crop tolerance") has been one goal to improve weed management systems (Callaway, 1992; Jordan, 1993). Another goal has been to improve the crop's ability to suppress weed growth and fecundity either through genetic improvements or cultural practices (Bussan et al., 1997; Callaway, 1992; Jannink et al., 2000; Liebman and Gallandt, 1997). Crop tolerance to weed interference aims to improve stability of yield and quality in weedy fields, whereas weed-suppressive ability targets the long-term management of weed populations by reducing seedbank size.

As commercial hybrids have been improved over the decades, direct and indirect selection has resulted in variation in corn canopy properties that determine outcomes in competition for light (Duvick, 2005). Variation in leaf area index and intercepted photosynthetically active radiation (PAR) among hybrids were reported to be responsible for differences in grain yield and weed suppression (Begna et al., 2001a, 2001b; Lindquist and Mortensen, 1999; Tollenaar et al., 1994). Several traits, including maximum LAI, rate of canopy closure, height of LAI, and leaf architecture, may improve weed-suppressive ability and dent corn tolerance to weed interference (Lindquist et al., 1998; Sankula et al., 2004; Tollenaar and $\mathrm{Wu}, 1999)$.

Literature on dent corn may have limited application to weed ecology and management in sweet corn. Grain yield at physiological maturity (R6: see Ritchie et al., 2003) is the primary crop response variable reported for studies of dent corn/weed interactions. Such data have relatively minor practical value for sweet corn because weeds compete with sweet corn for a shorter period of time than with dent corn and sweet corn is harvested at the milk stage (R3). Sweet corn is differentiated from dent corn by genes affecting starch synthesis in the endosperm, field emergence, and growth (Azanza et al., 1996; Tracy, 2001). The much wider range of planting dates in the north central United States for sweet corn compared with dent corn has a significant effect on yield loss resulting from weed interference (Williams, 2006).

Little has been published about the extent of variation in canopy properties among sweet corn hybrids. Pataky (1992) reported total leaf area ranged from 2540 to $4660 \mathrm{~cm}^{2}$ per plant among 11 hybrids with different levels of resistance to northern leaf blight. Makus (2000) showed differences in height and light interception between an earlyseason hybrid, Sensor, and the midseason hybrid, G-90. Effect of sweet corn hybrid was more important than row spacing for intercepting PAR and influencing growth of wild proso millet (Panicum miliaceum) and green foxtail (Setaria faberi) (Bisikwa, 2001).

Whether canopy properties of sweet corn influence crop/weed interactions will depend on the extent of variation in canopy development among hybrids. Characterization of crop canopy development, relative differences among hybrids, and relationships of canopy properties to crop yield are important in understanding competition for light in sweet corn. Therefore, the objectives of this work were to quantify canopy development and light environment among sweet corn hybrids under weed-free conditions and determine associations among canopy characteristics and crop yield.

\section{Materials and Methods}

Site description. Field experiments were conducted in 2004 and 2005 at the University of Illinois Crop Sciences Research and Education Center near Urbana, Ill., and the Washington State University Roza Unit near Prosser, Wash. The soil at Illinois was Flanagan silt loam (fine, smectitic, mesic Aquic Argiudolls) with $3.6 \%$ organic matter and $\mathrm{pH}$ of 6.4. Soil at Washington was Warden sandy loam (coarse silty, mixed, superactive, mesic Xeric Haplocambids) with $0.9 \%$ organic matter and $\mathrm{pH}$ of 6.5. Experiments were 
Table 1. Planting dates, crop emergence dates, crop stand, height, harvest dates, and yield of marketable ears for experiments near Urbana, Ill., and Prosser, Wash., in 2004 and 2005.

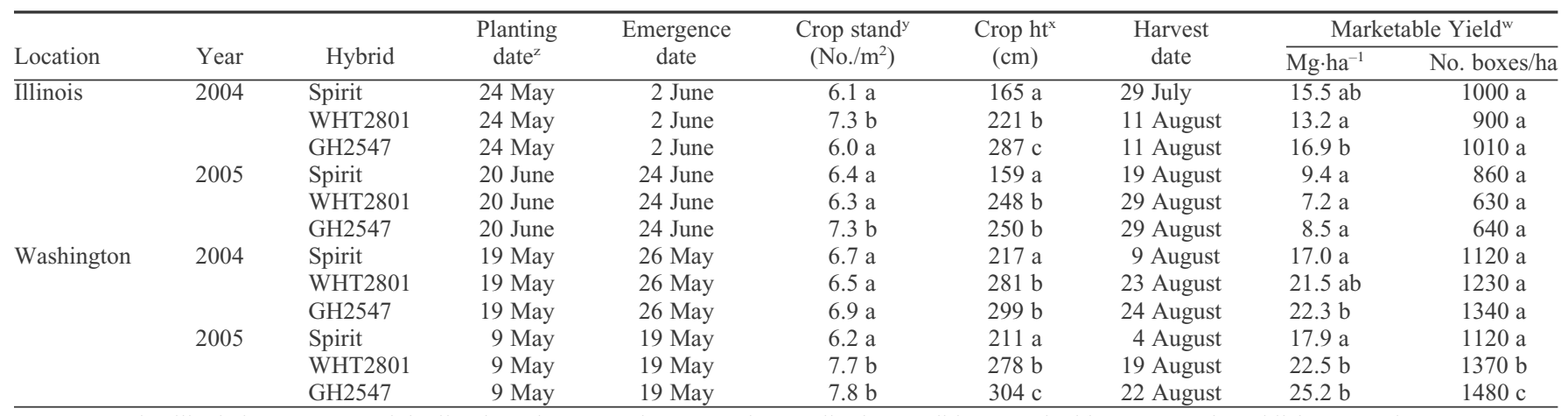

${ }^{2}$ Sweet corn in Illinois in 2005 was originally planted 23 May; however, abnormally dry conditions resulted in poor stand establishment and sweet corn was replanted 20 June.

${ }^{y}$ Entries represent the mean of four replications. Within each location-year combination, means followed by the same lower case letter were not significantly different at $P<0.05$ as determined by a protected, Bonferroni-corrected multiple comparison test.

${ }^{\mathrm{x}}$ Crop height was determined within $3 \mathrm{~d}$ of harvest of Spirit (H1).

"Marketable yield was determined by ears greater than $4.4 \mathrm{~cm}$ in diameter. One box $=50$ ears. Within each location-year combination, means followed by the same lower case letter were not significantly different at $P<0.05$ as determined by a protected, Bonferroni-corrected multiple comparison test.

Table 2. Sampling dates for canopy property measurements and corresponding crop growth stage (CGS) for experiments near Urbana, Ill., and Prosser, Wash., in 2004 and $2005^{z}$ (days from emergence to anthesis are included).

\begin{tabular}{|c|c|c|c|c|c|c|c|}
\hline \multirow{2}{*}{ Location } & \multirow[b]{2}{*}{ Year } & \multirow[b]{2}{*}{ Hybrid } & \multicolumn{4}{|c|}{ Sampling event } & \multirow[b]{2}{*}{ Days to anthesis } \\
\hline & & & V6 & R1 & H1 & $\mathrm{H} 2$ & \\
\hline & & & \multicolumn{4}{|c|}{ Date } & \multirow{8}{*}{$\begin{array}{l}39 \\
51 \\
51\end{array}$} \\
\hline \multirow[t]{12}{*}{ Illinois } & 2004 & & 17 June & 7 July & 29 July & 11 Aug. & \\
\hline & & & \multicolumn{4}{|c|}{ CGS } & \\
\hline & & Spirit & V6 & R1 & R3 & R4 & \\
\hline & & WHT2801 & V6 & VT & R2 & R3 & \\
\hline & & GH2547 & V6 & VT & $\mathrm{R} 2$ & $\mathrm{R} 3$ & \\
\hline & & & \multicolumn{4}{|c|}{ Date } & \\
\hline & \multirow[t]{6}{*}{2005} & & 13 July & 29 July & 17 Aug. & 30 Aug. & \\
\hline & & & \multicolumn{4}{|c|}{ CGS } & \multirow{6}{*}{$\begin{array}{l}38 \\
45 \\
47\end{array}$} \\
\hline & & Spirit & V6 & $\mathrm{R} 1$ & R3 & R4 & \\
\hline & & WHT2801 & V6 & V12 & R1 & R3 & \\
\hline & & GH2547 & V6 & V12 & R1 & R3 & \\
\hline & & & \multicolumn{4}{|c|}{ Date } & \\
\hline \multirow[t]{11}{*}{ Washington } & 2004 & & 30 June & 23 July & 9 Aug. & 24 Aug. & \\
\hline & & & \multicolumn{4}{|c|}{ CGS } & \multirow{6}{*}{$\begin{array}{l}55 \\
68 \\
68\end{array}$} \\
\hline & & Spirit & V6 & R1 & R3 & $\mathrm{R} 4$ & \\
\hline & & WHT2801 & V6 & V12 & R1 & R3 & \\
\hline & & GH2547 & V6 & V12 & R1 & R3 & \\
\hline & & & \multicolumn{4}{|c|}{ Date } & \\
\hline & \multirow[t]{5}{*}{2005} & & 17 June & 14 July & 5 Aug. & 22 Aug. & \\
\hline & & & \multicolumn{4}{|c|}{ CGS } & \\
\hline & & Spirit & V6 & R1 & R3 & $\mathrm{R} 4$ & 56 \\
\hline & & WHT2801 & V6 & V12 & R2 & R3 & 71 \\
\hline & & GH2547 & V6 & V12 & R2 & R3 & 70 \\
\hline
\end{tabular}

${ }^{\mathrm{z}}$ Crop growth stages were determined according to Ritchie et al. (2003).

located in different fields in each year. The previous crop was soybean at Illinois and dent corn at Washington. Fields in Illinois received $\mathrm{N}$ at $52 \mathrm{~kg} \cdot \mathrm{ha}^{-1}, \mathrm{P}$ at 46 $\mathrm{kg} \cdot \mathrm{ha}^{-1}$, and $\mathrm{K}$ at $54 \mathrm{~kg} \cdot \mathrm{ha}^{-1}$ on $23 \mathrm{Mar} .2004$ and $\mathrm{N}$ at $52 \mathrm{~kg} \cdot \mathrm{ha}^{-1}, \mathrm{P}$ at $52 \mathrm{~kg} \cdot \mathrm{ha}^{-1}$, and $\mathrm{K}$ at $67 \mathrm{~kg} \cdot \mathrm{ha}^{-1}$ on $16 \mathrm{Mar}$. 2005. Fields in Washington received $\mathrm{N}$ at $319 \mathrm{~kg} \cdot \mathrm{ha}^{-1}, \mathrm{P}$ at $79 \mathrm{~kg} \cdot \mathrm{ha}^{-1}$, and $\mathrm{K}$ at $168 \mathrm{~kg} \cdot \mathrm{ha}^{-1}$ on 10 May 2004 and $\mathrm{N}$ at $224 \mathrm{~kg} \cdot \mathrm{ha}^{-1}, \mathrm{P}$ at $59 \mathrm{~kg} \cdot \mathrm{ha}^{-1}$, and $\mathrm{K}$ at $186 \mathrm{~kg} \cdot \mathrm{ha}^{-1}$ on 2 May 2005. The experimental area was chisel-plowed in the fall or spring followed by one pass each of a disk harrow and a field cultivator before planting.
Experimental approach. The experimental design was a randomized complete block with four replications. Plots measured $12.2 \mathrm{~m}$ in length $\times 3.0 \mathrm{~m}$ in width. Sweet corn hybrids Spirit, WHT2801, and GH2547 were planted in 76- $\mathrm{cm}$ rows with a four-row planter (Table 1). All hybrids were sugaryl endosperm mutants. Spirit is an early-season hybrid, whereas WHT2801 and GH2547 are midseason hybrids. Fields were planted at $70,400 \mathrm{seeds} / \mathrm{ha}$ in Illinois and 77,800 seed ha in Washington. Planting dates are reported in Table 1.

At Illinois, a preemergence application of $S$-metolachlor at $1.78 \mathrm{~kg} \cdot \mathrm{ha}^{-1}$ a.i. and atrazine at $2.2 \mathrm{~kg} \cdot \mathrm{ha}^{-1}$ a.i. was applied to the study the day of crop planting. Lambda-cyhalothrin at $26 \mathrm{~g} \cdot \mathrm{ha}^{-1}$ a.i. or permethrin at $168 \mathrm{~g} \cdot \mathrm{ha}^{-1}$ a.i. was applied as needed to control Western corn rootworm (Diabrotica virgifera LeConte) beetles. In Washington, a preemergence application of atrazine at $1.12 \mathrm{~kg} \cdot \mathrm{ha}^{-1} \mathrm{a} . \mathrm{i}$. was applied within a day of crop planting. Weed escapes were removed by hand.

Experimental sites in Washington were furrow-irrigated on average $44 \mathrm{~cm}$ each year. The experimental site in 2005 in Illinois was sprinkler-irrigated twice (2 July and 8 Aug.) and each irrigation event totaled $2.5 \mathrm{~cm}$ of water to offset abnormally low rainfall.

Data collection. Leaf area index and intercepted PAR were quantified four times during the growing season (Table 2). Sampling events coincided within $3 \mathrm{~d}$ of: six leaves (V6) of Spirit, anthesis (R1) of Spirit, harvest $(\mathrm{H} 1)$ of Spirit, and harvest $(\mathrm{H} 2)$ of WHT2801 and GH2547. Growth stages were determined by the number of visible leaf collars and appearance of reproductive organs (Ritchie et al., 2003). Two plants were harvested, leaves were separated, and green leaf area was measured using an area meter (LI3100C Area Meter; LI-COR, Lincoln, Neb.). Plants selected for harvest were located in rows 1 or 4 at V6, and for remaining sampling dates, rows two or three and at least $1 \mathrm{~m}$ from the location of previously harvested plants. Leaf area index at each sampling date was estimated as the product of mean leaf area per plant and number of plants per square meter. Quantity of $P A R$ intercepted by the plant canopy was measured under full-sun conditions at three locations within each plot using a linear ceptometer (AccuPAR Linear Par Ceptometer PAR-80; Decagon Devices, Pullman, Wash.). Two measurements of incident PAR were taken: one measurement above the crop canopy followed by one at the soil surface with the sensor perpendicular to and centered over row two or three. All measurements were taken between $10 \mathrm{AM}$ and 2 PM on each date to minimize the influence of solar zenith angle 

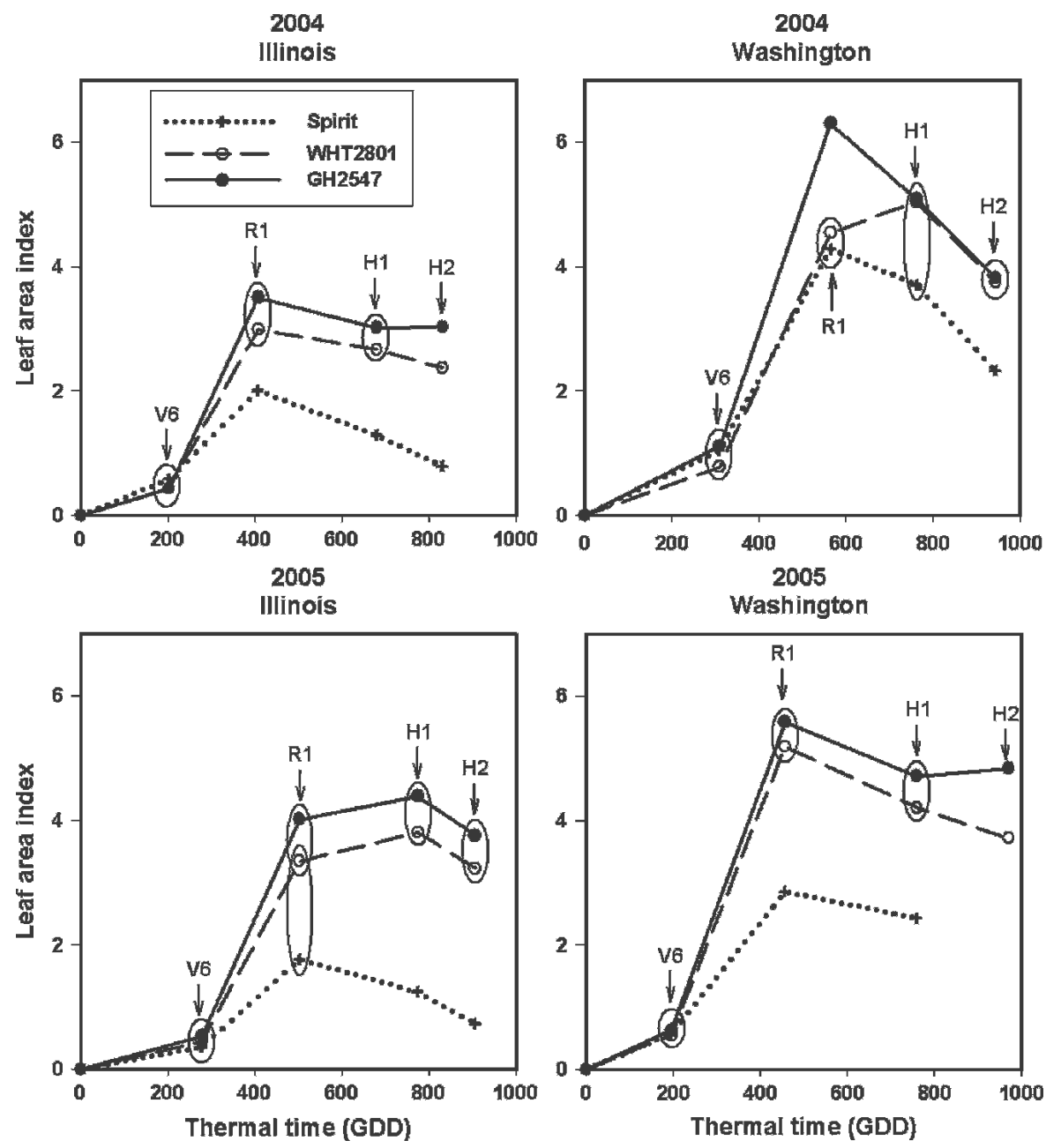

Fig. 1. Leaf area index of three sweet corn hybrids in Urbana, Ill., and Prosser, Wash., in 2004 and 2005. An ellipse is drawn around hybrids with similar leaf area indices and hybrids not included within an ellipse are different $(P \leq 0.05)$ at that sampling time. Sampling dates coincided within $3 \mathrm{~d}$ of: six leaves (V6) of Spirit, anthesis (R1) of Spirit, harvest (H1) of Spirit, and harvest (H2) of WHT2801 and GH2547.

on $P A R$ attenuation. Intercepted $P A R$ was estimated as unity minus the fraction of the soil-surface to above-canopy measurements and then averaged for each plot. Vertical LAI was determined at the $\mathrm{H} 1$ sampling event. Two plants per plot were divided into $30-\mathrm{cm}$ intervals from the soil surface to the top of the canopy. Leaves in each interval were separated and measured for leaf area as described previously.

Both functional and classic growth analysis (Hunt, 1982) were used to compare the canopy characteristics of sweet corn over thermal time (Russelle et al., 1984). An instantaneous value for maximal relative growth rate with respect to leaf area, $\mathrm{RGR}_{\max }$, was calculated by fitting a third-order polynomial function to LAI over thermal time (Hunt, 1982; SYSTAT Software, 2004) and finding the maximum of the first derivative of this function. The leaf area duration (LAD) of each of the three hybrids was calculated as the integral under the LAI curve across thermal time (Hunt, 1990). Finally, late-season change in LAI was calculated as the magnitude of the change in LAI between the R1 and H1 stages.
Marketable ears were hand-picked 18 to $24 \mathrm{~d}$ after anthesis from the center two rows over $6.1 \mathrm{~m}$ of the row. Stand counts were taken over the harvest area and harvest dates are reported in Table 1. Ears were considered marketable if $90 \%$ of kernels were full, yellow, and had a gravimetric moisture content of $75 \% \pm 3 \%$. Ears (including silks + husks) meeting these criteria exceeded $4.4 \mathrm{~cm}$ in diameter. Total number and mass of marketable ears were recorded. Number of ears per unit area were converted to boxes of ears assuming 50 ears per box. Within $3 \mathrm{~d}$ of Spirit harvest, plants were measured for height from the soil surface to the tip of the tassel.

Growing degree days (GDD) were determined using minimum and maximum air temperatures from a nearby weather station. A base temperature of $10^{\circ} \mathrm{C}$ was used as the minimum temperature for corn growth, and $30{ }^{\circ} \mathrm{C}$ was used as the air temperature associated with optimal growth. The time of crop emergence was used as the reference point for accumulation of GDD.

Statistical analyses. Before analysis, all data were examined for homogeneity of variances using the modified Levene's test
(Neter et al., 1996). Variances were found to be nonhomogeneous between sites and years; therefore, analyses were performed within site-year combinations. Diagnostic tests of residuals within each site-year indicated data complied with analysis of variance assumptions of homoscedasticity and normality; therefore, data were not transformed. After analysis of variance for each parameter (SYSTAT Software, 2004), means were compared using protected, Bonferroni-corrected multiple comparisons (Neter et al., 1996). A post hoc analysis of covariance (Neter et al., 1996) was applied to certain parameters such as LAI and stand height to rule out contributions of variation in agronomic conditions to sweet corn hybrid differences in canopy characteristics. Pearson correlations were subjected to Bonferroni corrections to account for multiple parameters being examined simultaneously.

\section{Results and Discussion}

Leaf area index. Development of LAI varied among hybrids. Hybrid GH2547 had the highest LAI from the R1 sampling date through the end of the season, whereas Spirit had the lowest (Fig. 1). Hybrid WHT2801 had an intermediate LAI that was often similar to one of the other hybrids. No differences in LAI among hybrids were observed at the V6 sampling date. Leaf area index peaked at the R1 sampling date and declined at later sampling dates as leaves senesced. Averaged over years, LAI at the R1 sampling time in Illinois was $1.9,3.2$, and 3.8 for Spirit, WHT2801, and GH2547, respectively. Mean LAI at the R1 sampling time in Washington was 3.6, 4.9, and 5.6 for Spirit, WHT2801, and GH2547, respectively. Stand counts varied among hybrids in three of four site-years (Table 1), but analysis of covariance results indicated that variation in stand did not have a significant effect on hybrid differences in LAI. As an example, Spirit had consistently lower LAI even when stand counts were similar to WHT2801 or GH2547.

Intercepted PAR. Intercepted PAR estimates also varied among hybrids. Hybrids WHT2801 and GH2547 had similar intercepted $P A R$ in all site-years with the exception of the $\mathrm{H} 2$ sampling date in Washington in 2005 (Fig. 2). Intercepted $P A R$ of Spirit was less than the other two hybrids in Illinois at the $\mathrm{H} 1$ sampling date and beyond in 2004 and the R1 sampling date and beyond in 2005 . Spirit-intercepted $P A R$ was similar to one or both of the other hybrids in Washington with one exception; intercepted $P A R$ of Spirit at the V6 sampling date in 2004 exceeded WHT2801 and GH2547. Averaged over years, intercepted $P A R$ at the R1 sampling time in Illinois was 77, 86, and 90 for Spirit, WHT2801, and GH2547, respectively. Mean intercepted $P A R$ at the $\mathrm{R} 1$ sampling time in Washington was 95, 97, and 96 for Spirit, WHT2801, and GH2547, respectively.

Vertical leaf area index distribution. Spirit was the shortest hybrid, averaging 162 and $214 \mathrm{~cm}$ in Illinois and Washington, 

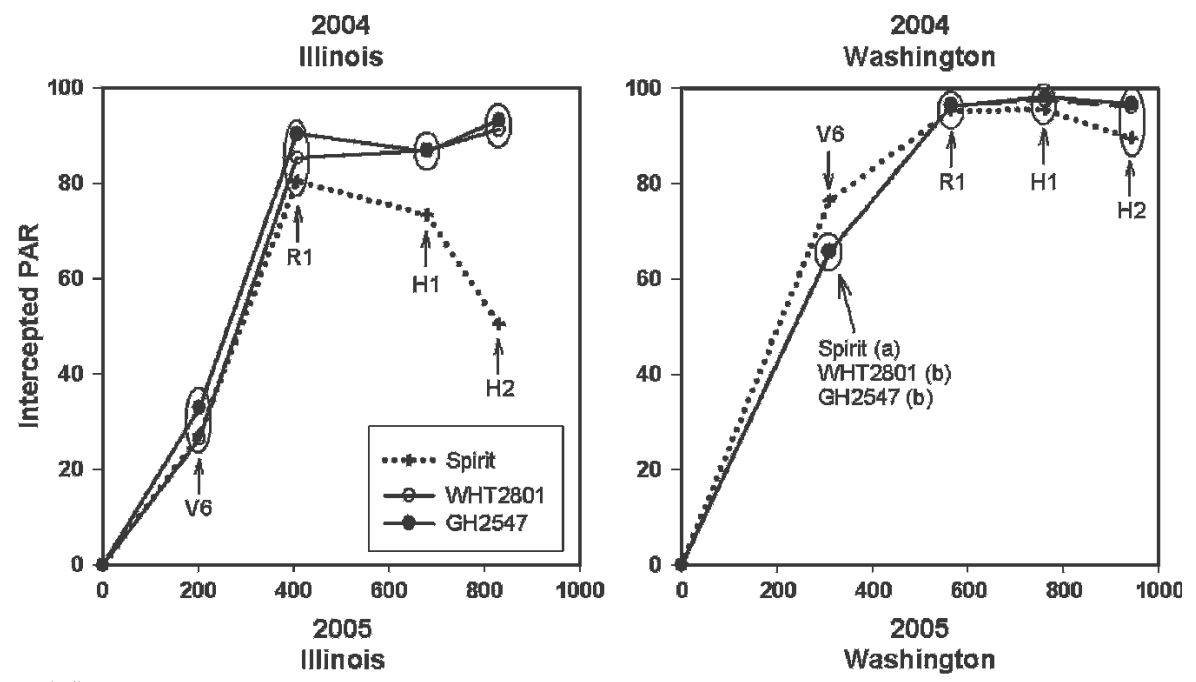

hybrid (Table 4). Intercepted $P A R$ at the V6 and R1 sampling dates were also correlated (0.58-0.83) with crop yield for each hybrid. Significant positive associations to crop yield were observed with height, $\mathrm{RGR}_{\max }$, and LAD. These associations make sense in that they describe increases in the size and duration of the canopy, which would enhance ability to capture light in mixed canopies. Duvick (2005) found that the genetic improvements in corn cultivars over a 50-year period were related to changes in characteristics that mitigated stresses. As an example, newer hybrids tend to be more tolerant of the stresses of higher plant density compared with older hybrids, enabling the use of higher plant density to maximize yield.

Implications for light competition. Significant variation in canopy properties exists among sweet corn hybrids. Crop height, leaf area, and vertical leaf area distribution varied widely, with the greatest differences observed during the latter half of the season. Moreover, these properties influenced the hybrids' ability to intercept light. GH2547 had the densest canopy, Spirit had the least dense canopy, and WHT2801 was often intermediate. Variation in some or all of the canopy properties may be even greater for earlier maturity hybrids because height is often reduced and growth is more susceptible to heat and drought stress compared with later-maturing hybrids (Tracy, 2001).

Differences in canopy properties influence interception of solar radiation and are likely to have implications for light competition and weed management. Light transmittance through a corn canopy stimulates weed emergence (Egley, 1986), growth (McLachlan et al., 1993), and fecundity (Lindquist and Mortensen, 1998; McLachlan et al., 1993; Sankula et al., 2004) of several weed species. In our study, late-season $(>500$ GDD and beyond) $P A R$ interception was variable among hybrids, particularly in Illinois where Spirit failed to capture $27 \%$ to $35 \%$ PAR at harvest. Furthermore, vertical leaf area distribution of the crop influences the height at which light is available to the weed and can alter crop/weed interactions. Lindquist and Mortensen $(1998,1999)$ found that when leaf area distribution occurred higher in the canopy, the crop was more effective at capturing $P A R$ than velvetleaf, thus increasing the crops competitiveness for light. McLachlan et al. (1993) report that as crop canopy density increased, redroot pigweed had fewer branches, allocated more biomass to the main stem, and had a greater proportion of leaf area in the upper canopy. We hypothesize WHT2801 and GH2547 would have greater weed-suppressive ability than Spirit when light is limited because WHT2801 and GH2547 have more leaf area distributed higher in the canopy capturing light at greater heights than Spirit.

Further development of the mechanistic understanding of corn-weed competition may lead to improvements in ecologic approaches for weed management (Lindquist et al., 1998; Rajcan and Swanton, 2001; 

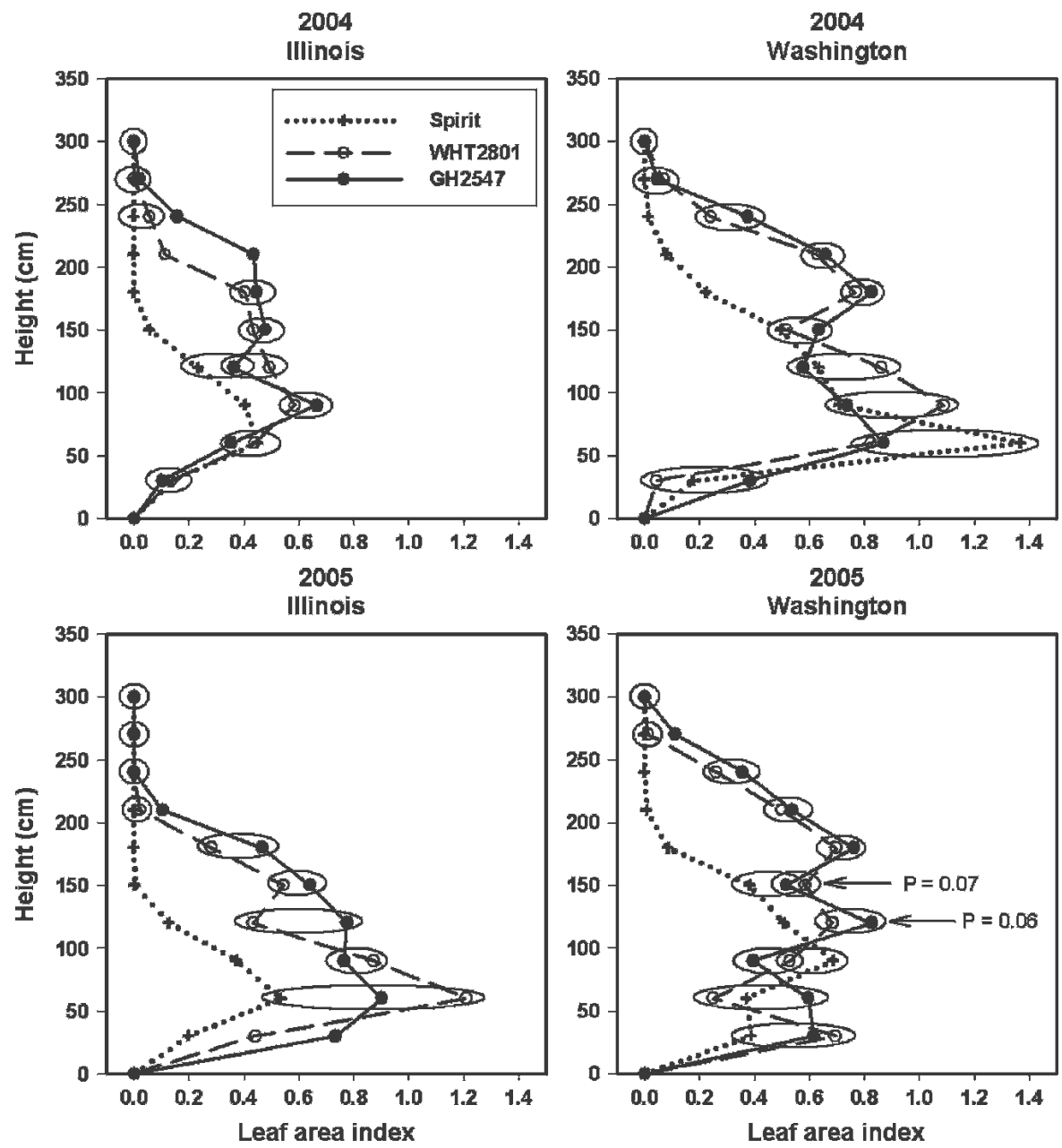

Fig. 3. Vertical leaf area index of three sweet corn hybrids in Urbana, Ill., and Prosser, Wash., in 2004 and 2005. Sampling time was at harvest of the hybrid Spirit (H1). An ellipse is drawn around hybrids with similar leaf area indices and hybrids not included within an ellipse are different $(P \leq 0.05$ unless otherwise stated) at that canopy height.

Table 3. Correlation between leaf area index, stratified within vertical levels, and total intercepted $P A R$ for three sweet corn hybrids across study sites in Urbana, Ill., and Prosser, Wash., in 2004 and 2005.

\begin{tabular}{|c|c|c|c|c|c|c|c|c|c|}
\hline \multirow[b]{2}{*}{ Hybrid $(n=16)$} & \multicolumn{9}{|c|}{ Vertical levels $(\mathrm{cm})$} \\
\hline & $0-30$ & $30-60$ & $60-90$ & $90-120$ & $120-150$ & $150-180$ & $180-210$ & $210-240$ & $240-270$ \\
\hline & \multicolumn{9}{|c|}{ Correlation coefficient } \\
\hline Spirit & 0.29 & 0.37 & 0.60 & $0.82 *$ & $0.84 *$ & $0.70^{*}$ & 0.34 & 0.28 & \\
\hline WHT2801 & 0.22 & -0.29 & 0.03 & 0.41 & 0.32 & $0.64 *$ & $0.87^{*}$ & $0.77 *$ & 0.47 \\
\hline GH2547 & 0.13 & 0.23 & -0.21 & 0.19 & -0.04 & $0.74 *$ & $0.67^{*}$ & $0.73 *$ & 0.22 \\
\hline
\end{tabular}

$* P<0.05$

Table 4. Correlation between crop canopy properties and yield of three sweet corn hybrids across study locations in Urbana, Ill., and Prosser, Wash., in 2004 and $2005 .{ }^{2}$

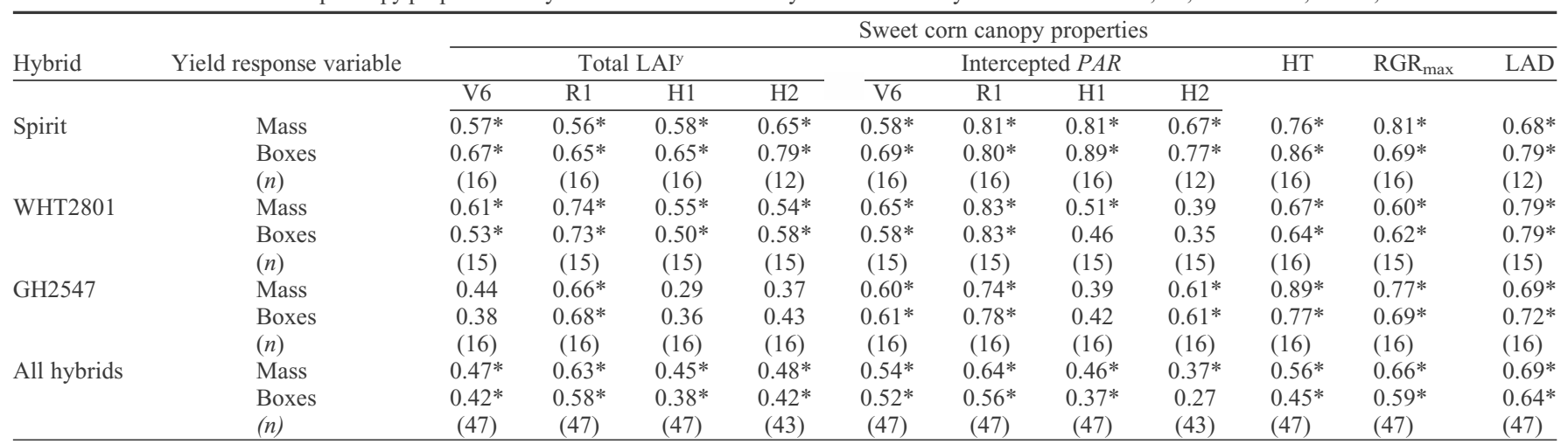

${ }^{2}$ Pearson correlations were Bonferroni-corrected.

${ }^{\mathrm{y}} \mathrm{LAI}=$ leaf area index; $P A R=$ photosynthetically active radiation; $\mathrm{HT}=$ height at $\mathrm{R} 1 ; \mathrm{RGR}_{\max }=$ maximal relative growth rate, determined as a function of leaf area index; $\mathrm{LAD}=$ leaf area duration, measured as the integral of the LAI over time; V6 = the point in time when hybrid Spirit had six leaves; R1 = the point in time when hybrid Spirit was at anthesis; $\mathrm{H1}=$ the point in time when hybrid Spirit was harvested; and $\mathrm{H} 2=$ the point in time when hybrids WHT2801 and GH2547 were harvested. $* P<0.05$.
Zimdahl, 2004). This work in sweet corn light competition in dent corn (Lindquist et al., 1998), namely maximum LAI and height at which LAI occurs, and these results may be useful in guiding future breeding efforts to improve sweet corn competitive ability. Characterization of vertical LAI of crop identifies location of light intercepRajcan and Swanton (2001) surs of incident $P A R$, although direct competition for light is likely greater in sweet corn because of the short stature of the plant and lower plant population density.

Our study found that some of the largest differences in canopy properties of the three hybrids occurred at the R1 sampling date, a time near maximum LAI. This sampling date also corresponded to a time in which changes in canopy structure, as measured by LAI and intercepted $P A R$, was associated with changes in crop yield for all hybrids. Kernel set occurs in the interval between anthesis and silking, and environmental stress such as drought during this interval has a particularly profound effect on crop yield (Bruce et al., 2002). Empiric comparison of sweet corn canopies suggests hybrids vary sufficiently to have differential effects on weed growth and may have differential responses to weed interference. Detailed study of crop/weed interactions warrants research, because knowledge of specific interactions is useful for developing practical guidelines (for example, cultivar selection or population density) or guiding efforts in crop breeding to improve weed management in sweet corn.

\section{Literature Cited}

Azanza, F., A. Bar-Zur, and J.A. Juvik. 1996 Variation in sweet corn kernel characteristics associated with stand establishment and eating quality. Euphytica 87:7-18.

Begna, S.H., R.I. Hamilton, L.M. Dwyer, D.W. Stewart, D. Cloutier, L. Assemat, K. ForoutanPour, and D.L. Smith. 2001a. Morphology and yield response to weed pressure by corn hybrids identifies some of the same traits important in flora in dent corn often receive less than $10 \%$ 
differing in canopy architecture. Eur. J. Agron. 14:293-302.

Begna, S.H., R.I. Hamilton, L.M. Dwyer, D.W Stewart, D. Cloutier, L. Assemat, K. ForoutanPour, and D.L. Smith. 2001b. Weed biomass production response to plant spacing and corn (Zea mays) hybrids differing in canopy architecture. Weed Technol. 15:647-653.

Bisikwa, J. 2001. Effects of canopy density on growth and development of wild proso millet and giant foxtail. MS Thesis, Univ. of Minnesota, St. Paul.

Bruce, W.B., G.O. Edmeades, and T.C. Barker. 2002. Molecular and physiological approaches to maize improvement for drought tolerance. J. Expt. Bot. 53:13-25.

Bussan, A.J., O.C. Burnside, J.H. Orf, E.A. Ristau, and K.J. Puettmann. 1997. Field evaluation of soybean (Glycine $\max$ ) genotypes for weed competitiveness. Weed Sci. 45:31-37.

Callaway, M.B. 1992. Compendium of crop varietal tolerance to weeds. A.J. Alt. Agr. 7:169180.

Duvick, D.N. 2005. The contribution of breeding to yield advances in maize (Zea mays L.). Adv. Agron. 86:83-145.

Egley, G.H. 1986. Stimulation of weed seed germination in soil. Rev. Weed Sci. 2:67-89.

Jannink, J.L., J.H. Orf, N.R. Jordan, and R.G. Shaw. 2000. Index selection for weed suppressive ability in soybean. Crop Sci. 40:10871094.

Jordan, N. 1993. Prospects for weed control through crop interference. Ecol. Appl. 3:84-91.

Hunt, R. 1982. Plant growth curves: The functional approach to growth analysis. Edward Arnold Publishers, Ltd., London.
Hunt, R. 1990. Basic growth analysis. Unwin Hyman, London.

Liebman, M. and E. Gallandt. 1997. Many little hammers: ecological approaches for management of crop-weed interactions, p. 78. In: L.E. Jackson (ed.). Agricultural ecology. Academic, San Diego.

Lindquist, J.L. and D.A. Mortensen. 1998. Tolerance and velvetleaf (Abutilon theophrasti) suppressive ability of two old and two modern corn (Zea mays) hybrids. Weed Sci. 46:569-574.

Lindquist, J.L. and D. Mortensen. 1999. Ecophysiological characteristics of four maize hybrids and Abutilon theophrasti. Weed Res. 39:271285.

Lindquist, J.L., D.A. Mortensen, and B.E. Johnson. 1998. Mechanisms of corn tolerance and velvetleaf suppressive ability. Agron. J. 90:787792.

Makus, D.J. 2000. Performance of two sweet corn cultivars grown under conservation tillage and with-in-row weed pressure. Subtropical Plant Sci. 52:18-22.

McLachlan, S.M., M. Tollenaar, C.J. Swanton, and S.F. Weise. 1993. Effect of corn-induced shading on dry matter accumulation, distribution, and architecture of redroot pigweed (Amaranthus retroflexus). Weed Sci. 41:568-573.

Neter, J., M.H. Kutner, C.J. Nachtsheim, and W. Wasserman. 1996. Applied linear statistical models. Irwin, Chicago.

Pataky, J.K. 1992. Relationships between yield of sweet corn and northern leaf blight caused by Exserohilum turcicum. Phytopathology 82:370-375.

Rajcan, I. and C.J. Swanton. 2001. Understanding maize-weed competition: Resource competi- tion, light quality and the whole plant. Field Crops Res. 71:139-150.

Ritchie, S.W., J.J. Hanway, G.O. Benson, and J.C. Herman. 2003. How a corn plant develops. Iowa State Univ. of Sci. and Technol. Coop. Ext. Serv, Spec. Rept. No. 48 (Revised).

Russelle, M.P., W.W. Wilhelm, R.A. Olson, and J.F. Power. 1984. Growth analysis based on degree days. Crop Sci. 24:28-32.

Sankula, S., M.J. VanGessel, and R.R. Mulford. 2004. Corn leaf architecture as a tool for weed management in two corn production systems. Weed Sci. 52:1026-1033.

Sinoquet, H. and R.M. Caldwell. 1995. Estimation of light capture and partitioning in intercropping systems. p. 79-80. In: H. Sinoquet, and P. Crus (eds.). Ecophysiology of tropical intercropping. Inst. Natl. de la Recherche Agronomique (INRA), Paris.

SYSTAT Software. 2004. Richmond, Calif.

Tollenaar, M., S.P. Nissanka, A. Aguilera, S.F. Weise, and C.J. Swanton. 1994. Effect of weed interference and soil nitrogen on four maize hybrids. Agron. J. 86:596-601.

Tollenaar, M. and J. Wu. 1999. Yield improvement in temperate maize is attributable to greater stress tolerance. Crop Sci. 39:1597-1604.

Tracy, W.F. 2001. Sweet corn. p. 155-197. In: A.R. Hallauer (ed.). Specialty corns, Second Ed. CRC Press, Boca Raton, Fla.

Williams, M.M. II. 2006. Planting date influences critical period of weed control in sweet corn. Weed Sci. (In press).

Zimdahl, R.L. 2004. Weed-crop competition: A review. Blackwell Publishing Ltd., Oxford, U.K. 